\title{
A Study of Supply Chain Management Practices in Finland and the United States
}

\author{
Karen Spens \\ Department of Marketing; Hanken School of Economics; \\ PB 479, 00101 Helsinki, FINLAND \\ Email: Karen.Spens@hanken.fi \\ Joel Wisner* \\ Department of Management; University of Nevada, Las Vegas; College of Business; \\ Box 456009, Las Vegas, Nevada 89154-6009, USA \\ Email: Joel.Wisner@unlv.edu
}

\begin{abstract}
Although for the past ten years there has been an abundance of research generally investigating various aspects of supply chain management (SCM), a lack of globally-based empirical studies examining actual SCM practices still exists. In this study, the overall objective was to identify, compare, and assess a number of SCM implementation and operating practices among firms in two highly developed and competitive economies, namely Finland and the United States. A survey identifying SCM experiences and practices among several industries was conducted and similarities and differences in supply chain management implementation experiences and operating practices were discovered. This research thereby develops a deeper understanding of the practice of SCM by looking at SCM attitudes and experiences among managers in firms from two advanced yet geographically dispersed economies. An associated practical objective of the study was to identify a set of supply chain management-oriented activities that will allow firms and their trading partners to enhance their overall effectiveness and market value.
\end{abstract}

Keywords: cross-national study, supply chain management practices, survey, Finland, United States

\section{Introduction}

Supply chain management (SCM) is viewed by many firms today as a difficult but necessary set of complex integrating activities, perhaps made more difficult by the expanding global marketplace, increased risk and security concerns, and the fact that some trading partners resist collaborating and sharing information-activities considered necessary for achieving any substantial level of SCM success. Generally speaking, SCM is defined as the coordination or integration (sharing information and working together) of key business processes among trading partners to improve the flow of goods, services and information, while reducing overall supply chain costs and maintaining the required levels of quality and customer service (Christopher 2004, Simchi-Levi et al. 2007). This ultimately leads to benefits for end customers as well as the supply chain trading partners. Thus, SCM is considered by many organisations proficient in the practice such as Wal-Mart, Dell, Proctor \& Gamble, and Toyota, to be a key contributor to a firm's competitiveness and overall success.

${ }^{*}$ Corresponding Author 
The practice of SCM is receiving a growing amount of interest from practitioners as well as academia, and many efforts to explain and describe the essence of SCM exist in the literature. Supply chain management has become such a popular topic that many business schools now offer courses and degree programs in SCM and a number of textbooks on the topic have also become available (see for instance Coyle et al. 2008, Meindl and Chopra 2006, and Wisner et al. 2008). Although for the past ten years there have been an abundance of research efforts investigating various aspects of SCM (see for example recent studies by Bendixen et al 2007, Feng and Yuan 2006, Locke and Romis 2007, Matthews 2006, Pearcy et al. 2007, Schoenherr and Mabert 2007, Sengupta et al. 2006, and Singh et al. 2007), a relative lack of globally-based empirical studies examining SCM practices related to actual implementations of the concept still exists.

Koh et al. (2007), in a cross-national study of U.S. and South Korean firms, provide empirical evidence for the connection between the organization's readiness for the internet and the impact of the internet on organizational performance. They argue that historically, an overwhelming majority of the studies on IT are focused on U.S. firms. Consequently there is an increasing need for studies conducted with a global perspective. Kaufmann and Carter (2006) also argue that international supply chain management topics represent a largely under-researched topic. In their study, a large-scale cross-national survey is conducted with supply managers in Germany and the U.S. Our study therefore supports this stated need for additional globally-based studies.

Companies operating in Finland and the U.S. were selected as the survey population sample in part because these countries are regarded as having two highly competitive economies. For example IMD, the International Institute for Management Development, in Lausanne Switzerland is one of the world's leading business schools and publishes the World Competitiveness Yearbook annually, wherein they rank the world's top 55 economies using 323 criteria. Their 2008 list ranked the U.S. 1st and Finland 15th in terms of overall competitiveness (Finland was ranked as high as 6th in 2005). Additionally, The Global Competitiveness Report, conducted annually by the World Economic Forum, an independent international organization incorporated as a Swiss not-for-profit foundation, reports survey findings from over 11,000 business leaders in 131 countries. In their 2008 report, the U.S. was ranked 1st and Finland was ranked 6 th in terms of overall competitiveness (in 2005, Finland was ranked 2nd). Thus, looking at the SCM practices of firms in these two countries should provide state-of-the-art information useful to both manufacturing and service company managers. Finally, the decision to survey Finnish companies was also based on the fact that English is commonly spoken, which simplified the survey's design.

This study builds on previous studies to develop a more complete understanding of the practice of SCM and to look at similarities and differences in SCM attitudes and experiences among firms from two advanced yet geographically dispersed economies, namely Finland and the United States. Finding supply chain management similarities and successes from firms within the two countries for instance, could provide strong support for firms considering use of a number of SCM practices. More specifically, the overall objectives were to identify, compare, and assess, using a survey, a number of supply chain management implementation and operating practices. Based on the results of a survey given to supply chain professionals in both countries, comparisons can be made and similarities and differences in supply chain implementation experiences and operating practices can be discovered. In addition, practitioners can learn valuable lessons by examining differences and comparing activities of managers in their country with those of another (Kaufmann and Carter, 2002). Thus, a secondary and practical objective of the study was to identify a set of activities that will potentially allow firms to enhance the overall effectiveness and market value of their firms and their supply chains.

In the following sections, a general overview of SCM practices and performance measures is provided, followed by a description of the respondent firms participating in the study. Finally, the results of the study are provided with some concluding remarks and directions for further research. 


\section{Supply Chain Management Practices}

SCM practices involve a set of activities undertaken within an organisation and integrated with its trading partners (suppliers and customers) to promote effective management of a supply chain (see for example Koh et al. 2007, Li et al. 2005 and 2006, and Frohlich and Westbrook 2001). Li et al. (2006) provided an overview of studies conducted on SCM practices, wherein the practices were listed. They found the literature to portray SCM practices from a variety of different perspectives with the common goal of ultimately improving overall organisational performance. They proposed five major components of SCM practice-strategic supplier partnerships, customer relationships, information sharing, the quality of information sharing, and postponement. In their study, they argued that the SCM practice construct has been validated, a construct which has generally been poorly defined and about whose meaning there is a high degree of variability. Koh et al. (2007) studied the underlying dimensions of SCM practices and empirically tested a framework identifying the relationships among SCM practices, operational performance and SCM-related organisational performance in small to medium sized enterprises (SMEs) in Turkey. They identified a number of SCM practices and proposed that they had a direct impact on the performance of SMEs with respect to flexibility, lead time, cost savings, resource planning, inventory levels, and forecasting. The authors found that the most prevalent practices were JIT supply, holding safety stock and having many suppliers, whereas outsourcing and 3PLs were less used. This finding is interesting as it indicates that differences exist between companies regarding the use of SCM practices. Frohlich and Westbrook (2001) studied the SCM process integration activities of firms in 23 countries and four continents. They found that in general, firms integrating processes with both suppliers and customers were associated with higher levels of firm performance.

Other SCM practices identified in the literature include long-term cooperative supplier/buyer relationships (Monczka et al. 1998, Heide and Stump 1995), frequent and informal exchanges of information (Stuart and McCutcheon 2000), outsourcing of logistics and other non-core activities (Stuart and McCutcheon 2000), formal evaluations of supplier performance (Shin et al. 2000), single or dual sourcing (Harland 1996), supplier development activities (Krause and Ellram 1997), and commitment, trust, and cooperation between key supply chain members (Walter et al. 2003). A brief review of several of these topics follows.

\subsection{Buyer/supplier relationships in supply chain management}

One relatively common assumption in supply chain management is that trading partners eventually develop trusting, long-term relationships wherein information sharing results, among other benefits, in more accurate forecasts, shorter order lead times, less use of safety stock and ultimately higher profits for the participants. Research studying the buyer/ supplier relationship has been conducted for quite some time (see for instance earlier work by Anderson and Narus 1990, and Ellram and Hendrick 1995). More recently, in interviews of 46 U.S. supply chain executives for example, Crook et al. (2008) found the sharing of cost and lead time information and project risk to result in economic gains for both partners. Petison and Johri (2008) interviewed Thai automobile manufacturing buyers and their suppliers and found their buyer/supplier partnerships to benefit both sides. Suppliers received technical and managerial support while the auto manufacturers received suppliers' knowledge of local production and market factors, fewer losses of classified information, and the ability to stop suppliers from working with competitors. Ogden and McCorriston (2007) surveyed hospitality industry managers and found the benefits of buyer/supplier partnerships to be time savings, greater reliability, better customer service, and greater flexibility.

Some studies however, have found mixed results in terms of support for buyer/supplier relationship benefits. Power (2008) for instance looked at supplier/ customer collaboration from the supplier perspectivehe found, in a survey of Australian manufacturers, that suppliers often perceived collaboration to be dictated by customers, collaboration costs were mostly borne by the suppliers, and the financial benefits were not readily apparent. Ogden and McCorriston (2007) found (in addition to the positive benefits mentioned earlier) that buyers frequently experienced supplier complacency from long-term suppliers. Vazquez et al. (2007) found in a Spanish food sector survey that 
opportunistic behavior can be exhibited in a buyer/ supplier relationship when the supplier believes they cannot be substituted. Consequently, an issue investigated in our study was the perceived benefits of supply chain management.

\subsection{Measuring supply chain performance}

Measuring the performance of supply chains can be a very difficult concept for supply chain participants to adopt or even understand, as performance can be measured and interpreted in so many different ways. In supply chains, the focus can often be on measuring and then averaging member costs, inventory levels, delivery times, or some other metric whereas in other cases, there may be no efforts undertaken at all to measure overall supply chain performance (see for instance Shin et al. 2000, Harland 1996, Krause and Ellram 1997, Walter et al. 2003). Thus, one of the main issues investigated by this study was how supply chain members actually measured the performance of their supply chains. More specifically, this study investigated both interfirm and intra-firm performance measures.

\subsection{Use of $3^{\text {rd }}$-party logistics service providers}

One can argue that globally, the extent to which third-party logistics (3PL) providers are being used has increased during the last decade. Small firms, lacking supply chain management expertise and the scale of business to justify purchasing logistics equipment, might decide to use 3PLs for this purpose. Some large firms such as General Motors have even opted to hire a lead logistics provider (termed 4PL) to manage all of their many 3PLs (Hannon 2001). Interestingly, a difference in 3PL usage was found between European and nonEuropean firms in several research papers. Lieb et al. (1993) for instance, found Western European firms to be more committed to outsourcing, as evidenced by the substantially greater percentage of their total corporate logistics budget allocated to third-party firms. Additionally, a more recent study of Mexican firms (Arroyo et al. 2006) indicates the existence of geographical differences in the use of 3PL providers, with Mexican companies not following the global outsourcing trend. It was thus concluded to explore this potential difference among U.S. and Finnish companies.

\subsection{Supply chain benefit sharing and the impacts of SCM on the firm}

To explore the level of commitment and cooperation among supply chain members leading to win/win results along the supply chain, it was desired to determine the level of monetary and non-monetary benefits being typically shared among supply chain participants. In regards to general descriptions of supply chain management in trade publications or textbooks, the long-term benefits of buyer/supplier process integration and relationship building are usually emphasised, with the end result being benefits for end consumers as well as all of the trading partners. Research in the fields of logistics and supply chain management also indicates that supply chain (SC) integration is considered one of the major factors in improving firm performance (van der Vaart and van Donk, 2008). Frohlich and Westbrook (2001) have provided empirical evidence of the association between firm performance and integration, and Corsten and Felde (2005) demonstrate that supplier collaboration has a positive effect on buyer performance in terms of both innovative capability and financial results. More recently, Forslund and Jonsson (2009) discuss to what degree supplier relationship obstacles and operational tool obstacles hinder supply chain integration of the performance management process. Vand der Vaart and van Donk (2008) in their article point out that there is little consensus on how to capture the essence of SC integration, or on how to measure the effects of SC integration on performance. The expectation is, nevertheless, that integration should eventually lead to the sharing of monetary and non-monetary benefits among the supply chain participants. Consequently, our study sought to investigate the levels and types of benefit sharing that occur among the respondents actively managing their supply chains.

In this study, the focus was on identifying and analysing how supply chain management practices have been applied among a wide range of U.S. and Finnish companies with regards to supply chain performance measures, supply chain benefit sharing, use of 3PL service providers, use of IT in supply chains, and any 2nd and 3rd tier integration efforts. Also of interest were the main motives and challenges for supply chain integration initiatives among the respondents. 


\section{Research Methodology}

A survey instrument was developed and circulated to the population sample via the Web. Web-based surveys have increasingly gained attention as their use has spread for business research purposes. Webbased surveys are significantly faster and much less costly to administer, and allow for a less timeconsuming data analysis period, however, there are indications that email surveys can receive significantly lower response rates when compared to standard mail surveys, particularly when surveys are lengthy (see for example Kaplowitz et al. 2004 and Johnson and Owens 2003). For the purposes of this study, an email survey was considered desirable, since all recipients had email addresses, and since the mailing costs from the U.S. to Finland and vice-versa was quite high. The authors were able to gain access to email address databases for major logistics and supply chain practitioners in both countries - for Finland companies, the leading logistics association LOGY, the Finnish Association of Purchasing and Logistic and their publication, Logistiikka, provided email contact information, while for the U.S. firms, email addresses were provided by the Institute for Supply Management (ISM).

The questionnaire for the survey was based on earlier supply chain studies performed by the authors, as well as information obtained from the current literature. A pre-test of the survey was conducted using several local academics and practicing logistics managers, and improvements to the survey were made based on this feedback. The email contact letter and questionnaire were administered in English, since English is commonly spoken and understood in Finland.

The email survey was sent to 976 U.S. and 286 Finnish company representatives at the same time. Three additional email reminders, each containing a copy of the survey, were sent to the Finnish and U.S. email addresses. Ultimately, a combined response rate of 12.3 percent was achieved (69 responses were Finnish, while 86 were U.S.). As response rates to industry surveys and in particular email surveys have declined dramatically over time, (Sax et al. 2003) and as cross-national surveys often exhibit low (6-16\%) response rates (Harzing, 2000), the response rate for this survey was considered acceptable albeit somewhat lower than desired.

\section{Results and Discussion}

\subsection{Describing the respondent firms}

The 155 survey respondents were typically purchasing, transportation, logistics or supply chain managers, while their firms were mainly final product manufacturers, wholesalers, distributors, and other services. The size of the companies ranged from quite small (14 percent had annual sales of U.S.\$25MM or less, and about 55 percent had fewer than 500 employees) to very large (15 percent had over U.S.\$1B in annual sales and 9 percent had 10,000 or more employees). Table 1 describes several SCM-oriented characteristics of the respondents. More than 77 percent of the entire sample reportedly practiced SCM (based on a SCM definition provided on the survey), while 75 percent of those firms had been engaged in SCM for 5 years or longer. Further, most of the respondents practicing SCM focused their supply chain efforts on key first-tier (direct) suppliers and to a lesser degree on direct customers, $2^{\text {nd }}$ tier suppliers and customers, and recycling activities. Interestingly, most of these respondents included relationships with transportation, warehousing, and other logistics services in their supply chain efforts. Finally, over 60 percent of these respondents had globally dispersed supply chains.

\subsection{Process integration in the supply chain}

The remaining tables provide further data for the group of respondents actively managing their supply chains. In Table 2, information is provided relating to three of the most important and current issues in the field of supply chain management, namely the integration of processes, measurement of supply chain performance, and outsourcing. Almost 80 percent of the companies managing their supply chains reported that they integrated processes or shared process activities with their supply chain members (specifically, this was 90 percent of the Finnish companies and 70 percent of the U.S. companies).

Some of the most interesting results regarding process integration related to the use of collaborative planning, forecasting and replenishment (CPFR), the linking of suppliers and customers to respondents' enterprise resource planning (ERP) systems, and the 
Table 1. A Description of the Respondent Firms

\begin{tabular}{|c|c|c|c|}
\hline Business Description & Percent & Origin of Firm & Percent \\
\hline Raw Mat'l. Extractor/Mfg. & 7.1 & US & 55.5 \\
\hline Component Manufacturer & 7.7 & Finland & 44.5 \\
\hline Final Product Manufacturer & 43.2 & & \\
\hline Wholesaler/Distributor & 12.9 & Firms Practicing SCM & Percent \\
\hline Other Services & 22.6 & US Firms & 81.4 \\
\hline \multirow[t]{2}{*}{ Others/No Response } & 6.5 & Finnish Firms & 72.5 \\
\hline & & Total sample & 77.4 \\
\hline Respondent Position with Firm & Percent & & \\
\hline Owner/Executive Officer & $\overline{10.3}$ & Years Practicing SCM & Percent \\
\hline Purchasing Mgr./Director & 36.1 & Less than 5 & 25.0 \\
\hline Transp./Log./Supply Chain Mgr. & 29.0 & $5-9$ & 31.7 \\
\hline Production/Quality Mgr. & 5.8 & $10-14$ & 16.7 \\
\hline Buyer & 9.7 & 15 or more & 25.0 \\
\hline Other/No Response & 9.1 & No response & 1.7 \\
\hline Annual Sales (\$US) & Percent & $\underline{\text { Supply Chain Efforts Include }}^{\mathrm{a}}$ & Percent \\
\hline$\$ 25 \mathrm{MM}$ or less & 14.2 & $1^{\text {st }}$ tier key suppliers & 80.8 \\
\hline \$25MM - \$100MM & 16.8 & $2^{\text {nd }}$ tier key suppliers & 4.2 \\
\hline$\$ 100 M M-\$ 1 B$ & 19.4 & $1^{\text {st }}$ tier key customers & 53.3 \\
\hline Over $\$ 1 \mathrm{~B}$ & 14.9 & $2^{\text {nd }}$ tier key customers & 0.8 \\
\hline \multirow[t]{2}{*}{ No response } & 34.8 & End customers & 0.0 \\
\hline & & Transp./whsing./logis. services & 62.5 \\
\hline Number of Employees & Percent & Recycling activities & 30.8 \\
\hline Fewer than 500 & 54.8 & & \\
\hline $500-999$ & 6.5 & $\underline{S u p p l y ~ C h a i n ~ C o v e r a g e ~}^{\mathrm{a}}$ & Percent \\
\hline 1000-9999 & 21.3 & Local & 7.5 \\
\hline 10000 or greater & 9.0 & Regional & 7.5 \\
\hline \multirow[t]{2}{*}{ No response } & 8.4 & National & 24.2 \\
\hline & & Global & 60.8 \\
\hline
\end{tabular}

use of vendor managed inventories (VMI). Regarding CPFR, well over half of both U.S. and Finnish companies reported that they used this collaborative forecasting method. Interestingly, the use of VMI is not reported at all in Finnish companies, whereas 70 percent of the U.S. companies used it. Unfortunately, our study provided no further evidence or causes to explain this difference. This might be an indication of the fact that VMI was designed to bring supply chain partners closer together, however it does not really focus on information sharing between partners, whereas CPFR captures the operational advantages and adds collaborative mechanisms to facilitate information exchange in a multi-tiered supply chain (Cassivi, 2006). The low implementation of VMI in Finland has also been pointed out by other researchers, who indicated that possible reasons for this could be the difficulties of suppliers to utilize the demand information directly in order to optmize their own capacities and warehouse allocations (Kauremaa, 2006).

Previous research has linked the use of ERP systems among supply chain members to better organizational performance. Dai (2008) for example found indications that ERP usage not only acted as a process integration device among global trading partners, but also positively impacted competitive advantage. Finnish companies also to a larger extent reported the linking of their ERP systems to their key suppliers' as well their key customers' ERP systems.

\subsection{Supply chain performance measures}


Overall performance of supply chains can be a very difficult concept to understand easily, as the concept can be used and measured in so many different ways. In many company settings, the focus may concentrate on reporting of financial performance and costs. One of the main issues investigated in our study was therefore how supply chain members actually measured supply chain performance. Questions concerning both inter-firm and intra-firm supply chain management performance measures were included as well as questions regarding use of the Balanced Scorecard (Kaplan and Norton 1996) and the SCOR model (Saccomano 1998)-two supply chain performance assessment tools.

In total, 60 percent of the 120 respondents managing their supply chains reported that they indeed measured the overall performance of their supply chains. Finnish firms indicated a higher percentage, with over 73 percent of these firms measuring supply chain performance compared to approximately 57 percent of the U.S. firms. Among the firms measuring supply chain performance, a wide range of measures were found to be in use. Two performance measures were found to be used by almost all of these firms-average supply chain member delivery performance (used by over 93 percent of this respondent group) and average perfect order fulfilment performance, or the average percentage of orders that arrived on-time, complete and damage free (86 percent of this group reported its use).

Regarding the remaining performance measures, the U.S. respondents had a slightly stronger focus on measuring total supply chain management costs, whereas the Finnish respondents placed a stronger focus on the supply chain members' e-business performance, measured in percent of orders received via the Internet or e-mail.

\subsection{Use of $3^{\text {rd }}$-party logistics service providers}

Generally, use of 3PLs has increased over the past decade. Earlier studies have shown that Western European firms were more committed to outsourcing, as evidenced by the substantially greater percentage of their total corporate logistics budget allocated to third-party firms (Lieb et al. 1993). In surveys on 3PL usage, it has also been confirmed that European firms spent a larger proportion of their logistics costs $(61 \%)$ on 3PL services than did firms in North America (44\%) (Langley et al. 2004). Also as mentioned earlier, a study by Arroyo et al. (2006) indicated that there were geographical differences in 3PL usage. Our survey supports these findings on the differences in outsourcing between U.S. and European firms. Of the firms managing their supply chains, nearly 78 percent of the Finnish respondents indicated they used 3PLs, compared to only 54 percent of the U.S. respondents. The 3PL companies most commonly used were transportation services, followed to a lesser degree by warehousing and freight forwarding services. This is in line with the survey findings from a decade ago (Gooley 1997), which indicated that the most frequently used third-party service was shipment consolidation, followed by fleet management/ operations and warehouse management. Interestingly, in our study, 90 percent of all respondents practicing SCM stated that 3PLs were considered key members of their supply chains (consisting of about 95 percent of the Finnish firms and 86 percent of the U.S. firms).

\subsection{Supply chain benefit sharing and the impacts of SCM on the firm}

In the practice of SCM, the benefits of process integration and collaboration among trading partners have usually been emphasised, resulting in win-win scenarios for the companies involved. This leads to the expectation of monetary and nonmonetary benefits being typically shared among supply chain participants. Nevertheless, as shown in Table 3, over half of the respondents managing their supply chains reported that they had no formal or structured method for sharing benefits, nor did they feel that the benefits were fairly shared by all members. In the case of Finnish companies, there was a much stronger sense of unfairness, as only about 45 percent of the respondents reported that the benefits were being shared fairly by all members in their supply chains. Further, 44 percent of the Finnish respondents believed that supply chain members with the most purchasing/negotiating power received the most benefits, while only 28 percent felt that those supply chain members performing the best were receiving the most benefits. Recalling the previous literature on buyer/supplier relationships, the somewhat mixed results of some of those studies appear to be reproduced here. 
Table 2. Process Integration in the Supply Chain ${ }^{\mathrm{a}}$

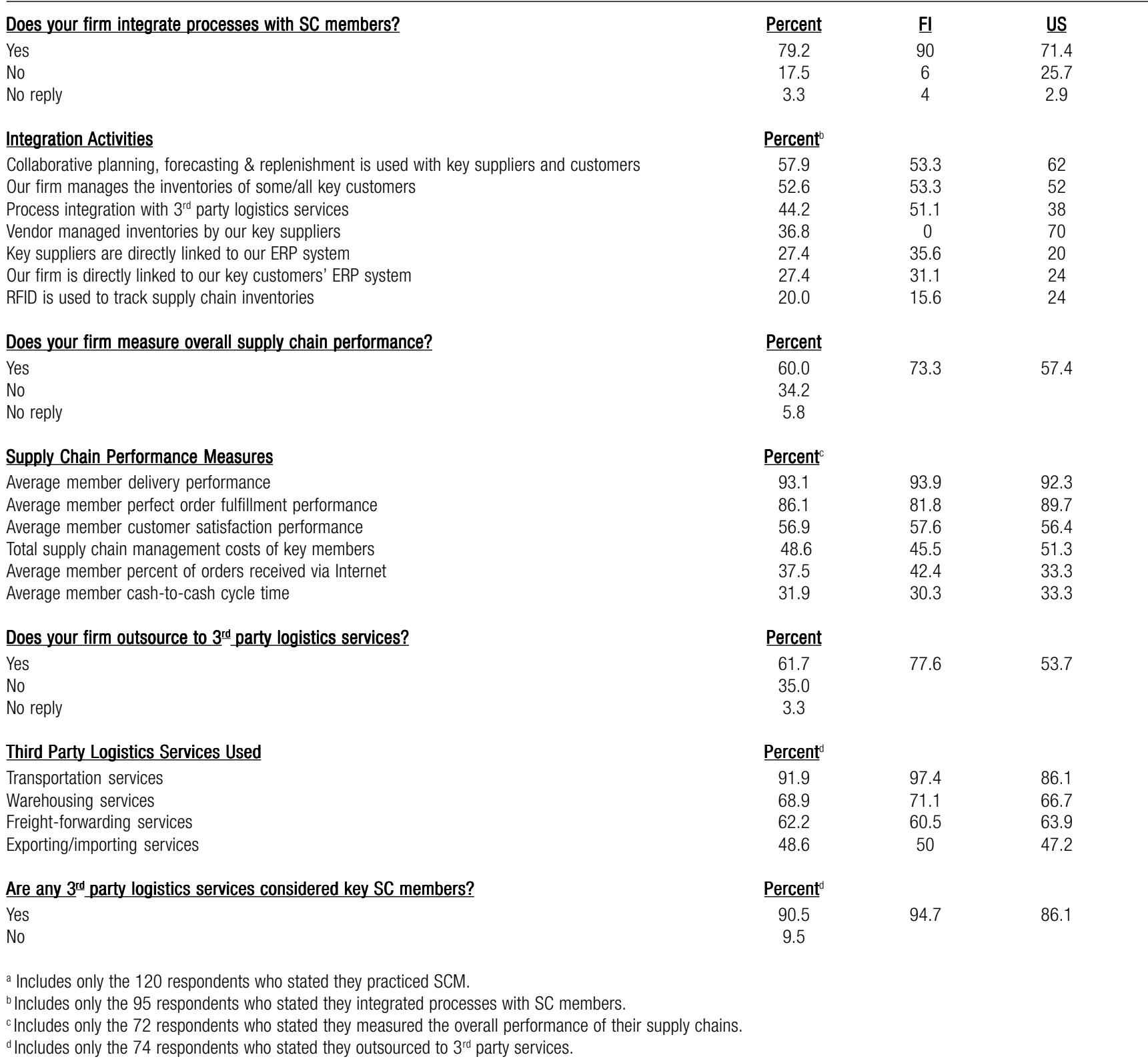

On the other hand, if we look at the impacts of SCM on the firm as shown in Table 4, we see that it is apparently viewed as enabling the firm to so strongly improve performance that even though benefits may not be fairly shared, SCM is still viewed as worthwhile. This finding is also somewhat supported by Corsten and Kumar (2003), wherein they noted that suppliers engaging in SCM with a dominant partner were still better off than suppliers not engaging in such a relationship. The impacts on profit are, however, not the only apparent reasons for conducting SCM. In addition, it enables firms to improve customer service, their reputations, their internal working environments, product quality, and market shares, as indicated in Table 4.

An additional aim of the survey was to discover items that are vital to SCM success. Some key items were found that in general related to supply chain management success. On the other hand, differences were also found between the responses of the two 
Table 3. Sharing the Benefits of $\mathrm{SCM}^{\mathrm{a}}$

\begin{tabular}{lcrrr}
\hline How are benefits shared among supply chain partners? & $\underline{\text { Percent }}$ & $\underline{\text { FI }}$ & $\underline{\text { US }}$ \\
No formal/structured method for sharing benefits & 58.3 & 64 & 54.3 \\
The benefits are shared fairly by all members & 53.3 & 44.7 & 64.2 \\
Members who perform the best get the most benefits & 36.7 & 28 & 42.9 \\
Firms with the most purchasing/negotiating power get the most benefits & 29.2 & 44 & 18.6 \\
& & & \\
a Includes only the 120 respondents who stated they practiced SCM. & &
\end{tabular}

Table 4. The Impacts of SCM on the Firm ${ }^{\mathrm{a}}$

\begin{tabular}{|c|c|c|c|c|}
\hline SCM enabled firm to improve: & Mean $^{b}$ & Std. Dev. & $\underline{\mathrm{FI}}$ & $\underline{\text { US }}$ \\
\hline Profits & 4.2 & .76 & 4.1 & 4.3 \\
\hline Customer service & 4.2 & .76 & 4.2 & 4.3 \\
\hline Reputation & 3.9 & .78 & 3.8 & 3.9 \\
\hline Internal work environment & 3.9 & .78 & 3.8 & 4.0 \\
\hline Quality & 3.8 & .92 & 3.6 & 4.0 \\
\hline Market share & 3.8 & .94 & 3.7 & 3.9 \\
\hline
\end{tabular}

countries. The main differences between U.S. and Finnish respondents were related to the use of 3PLs, the use of IS applications, the importance of $2^{\text {nd }}$ tier suppliers, the importance of environmental compliance, and finally the importance of ethical practices and reverse logistics performance, which can be seen in Table 5 .

\section{Conclusions and Directions for Future Research}

The practice of supply chain management has been widely touted in the popular press, reportedly resulting in lower prices, higher quality, and better service for trading partners as well as end product customers. Supply chain members acting together can thus become more competitive and ultimately be rewarded in terms of higher sales, profits and market shares. Our study found support for this, in that most respondents in both countries were indeed actively managing global or national supply chain networks. Given that both the United States and Finland have historically been rated highly in terms of overall competitiveness, this further supports the idea that SCM provides benefits to firms. Building supplier relationships was found to be the most common supply chain management activity, followed by the formation of 3PL relationships. SCM also appears to provide significant benefits to trading partners in terms of improved profits, customer service, reputation, and quality. The real issue of equitable benefit sharing among supply chain participants, however, does appear to be a problem which could undermine many SCM efforts, ultimately impacting overall supply chain performance if left unchecked. Supply chain trading partners stand to benefit even more if solutions to this problem can be found and implemented. To improve this situation, firms might consider establishing collaborative planning and benefits sharing procedures and policies, specifically related to applying monetary rewards, greater shares of purchasing spend, and other forms of benefit sharing for superior performance. Based on the findings of this study, it is evident that even though benefits might not be fairly shared, SCM is still viewed as very worthwhile.

A vital part of the study concerns the examination of current and future trends in the practice of SCM. If we relate this discussion to some of the more recent trends and lines of discussion in the field of logistics and supply chain management we can see that firms 
Table 5. Items Considered Important to SCM Success ${ }^{a}$

\begin{tabular}{|c|c|c|c|c|}
\hline SCM enabled firm to improve: & $\underline{\text { Mean }}^{b}$ & Std. Dev. & $\underline{F I}$ & $\underline{\text { US }}$ \\
\hline Key $1^{\text {st }}$-tier suppliers & 4.6 & .65 & 4.5 & 4.6 \\
\hline On-time delivery/customer service & 4.7 & .56 & 4.8 & 4.7 \\
\hline Product/service quality & 4.7 & .68 & 4.6 & 4.7 \\
\hline Key $1^{\text {st }}$-tier customers & 4.3 & .90 & 4.4 & 4.2 \\
\hline Use of $3^{\text {rd }}$-party SC services & 4.2 & .77 & 4.3 & 4.1 \\
\hline Use of I.S. applications & 4.2 & .99 & 4.4 & 4.1 \\
\hline Low cost/low price & 4.0 & .96 & 4.1 & 4.0 \\
\hline $2^{\text {nd }}$-tier suppliers & 3.7 & 1.03 & 3.5 & 3.8 \\
\hline SC member ethical practices & 3.7 & 1.15 & 3.1 & 4.1 \\
\hline $2^{\text {nd }}$-tier customers & 3.5 & 1.12 & 3.4 & 3.5 \\
\hline Reverse logistics performance & 2.9 & 1.12 & 3.2 & 2.7 \\
\hline Use of reverse auctions & 2.3 & 1.29 & 2.4 & 2.2 \\
\hline
\end{tabular}

are nowadays required to take on even broader responsibilities for the actions of their supply chains both environmentally as well as socially. Environmental concerns are seemingly of importance to companies in the U.S. as well as in Finland. However, with regards to the issue of recycling, an interesting difference between the responses of the two countries can be observed. In Finland, 36 percent of the respondents, compared to 27 percent of U.S. companies, stated that recycling activities were included in their supply chains. This could be due to the fact that recycling activities have been heavily endorsed by both Finnish legislation and similarly in the EU. For example, recycling of glass is heavily regulated and legally enforced in Finland, and Finland is today one of the leading countries in the world with regards to the recycling of glass material (GlasBanken, 2004).

Closely related to the environmental issues is the concern of ethical practices in supply chains. Failing to implement adequate ethical practices when dealing with suppliers and customers can lead to significant loss of trust and reputation, potentially impacting brand, which may have adverse impacts on shareholder value. Interestingly, this was only viewed as moderately important to the Finnish respondents, while it was given a somewhat higher importance by the U.S. respondents (the Finnish importance mean was 3.1 using a 5-point Likert scale, versus 4.1 in the U.S.). This is seemingly another trend that is moving slower in Finland than the U.S. For example, one of the most famous Finnish companies, Nokia, introduced ethical codes of conduct for their suppliers in the year 2000 (Nokia, 2008), however by 2000, U.S. companies had for quite some time been branding companies according to ethical principles, leaving their European competitors behind (Metsä, 2000). Nevertheless, ethical practices have received much attention recently from European companies due to regulations and legislation imposed on companies by the EU as well as the increasing pressure coming from consumers.

As this study indicates, there are more similarities between the two countries in terms of SCM practices than differences. The main differences concern the use of 3PLs, the perceived sharing of benefits between supply chain members, the use of VMI, and the importance of ethical practices among supply chain members. Similarities can be found when looking at the performance measures that are actually used by the respondents. The three most popular supply chain performance measures used were average supply chain member delivery performance, average perfect order fulfilment performance, and average customer satisfaction performance. Since the often-touted benefits of SCM are better customer service and product or service quality, the most important elements in terms of contributing to supply chain success were obvious and in fact, turned out to be very similar. Overall, it can be stated that firms taking part in this study exhibited a fairly deep understanding of the concepts and benefits of SCM and that SCM practices seem to have become quite global. Nevertheless, as the research has pointed out, there are geographical differences, implying that 
managers should be aware of possible differences between geographical regions when developing global supply chain strategies.

Future research opportunities exist in the identification and validation of SCM techniques and practices particularly suited to small manufacturing firms and services such as agricultural, fishing, and forestry companies. Over the past ten years, trading agreements between countries have become more commonplace, such as the Central American Free Trade Agreement and the Common Market of Eastern and Southern Africa. Thus, it would be interesting to identify cross-boundary SCM practices in these countries, to see if any significant changes have recently occurred due to the trade agreements. With the global expansion of supply chains, comes greater probabilities that supply chain risk and security issues will impact how supply chains are managed. Thus, new studies need to consider this aspect of global supply chains. Finally, environmental sustainability has become very important recently, both from a customer requirement standpoint and with respect to supply chain costs. Supply chain surveys need to begin addressing these issues as well.

\section{Limitations of the Study}

This study attempted to extend the understanding of supply chain management, ultimately to provide useful insights to researchers and to managers seeking to implement supply chain management practices and improve firm performance. This study, like others, has limitations. The random sample for the survey was obtained from the Institute for Supply Management and Logistiikka membership databases, thus, the results are generalizable only to the extent that the ISM and LOGY members resemble the population of all U.S. and Finnish firms, and that the respondents were knowledgeable about their firm's SCM efforts. The response rate was also somewhat low, however given the delivery method, length, complexity, and subject matter, this is considered reasonable. Some potential respondents may have decided not to reply once they learned the survey was primarily for firms practicing SCM. For this reason, the percentage of firms practicing SCM as shown in Table 1 may be overstated. Additionally, the survey mailings and returns covered a three-month time period, which may have introduced a slight time lag problem. The relatively low response rate also meant that tests of statistical significance could not be adequately performed when comparing most of the subsamples.

Readers should also note that much of the data reported here is based on management perceptions. Past research however, supports the use of qualitative assessments and has found them to be a reliable alternative to actual performance data (see for instance, Dess and Robinson 1984; Venkatraman and Ramanujam 1986). Because of the use of qualitative assessments from managers, firm performance data was not collected, and thus, only general overall performance assessments relative to competitors were requested.

Additionally, the term supply chain management, as alluded to in the opening paragraphs, is itself a confusing term and is interpreted quite differently across industry and academic groups alike. These varied perceptions may have played a role in the answers provided on the survey and could potentially have impacted the findings here. For this reason, a commonly used definition of supply chain management was provided on the survey. Finally, respondents whose firms did not practice SCM were not used in this study beyond the general sample description provided in Table 1.

In summary, while caution in designing the study and in collecting and analyzing data was used, cross-national studies do have inherent limitations. Therefore the results of this study should be interpreted in that context and generalized with care.

\section{Acknowledgements}

The authors would like to express their gratitude to the journal editor and the reviewers for their thoughtful comments and suggestions for improving this manuscript.

\section{References}

Arroyo, P., Gaytan, J. and Luitzen, de B. (2006). A survey of third party logistics in Mexico and a comparison with reports on Europe and USA International Journal 
of Operations E Production Management, 26(6), pp. 639667.

Anderson, J. and Narus, J. (1990). A model of distributor firm and manufacturer firm working partnerships Journal of Marketing, 54(1), pp. 42-58.

Bendixen, M., Abratt, R., and Jones P. (2007). Ethics and social responsibility in supplier-customer relationships Journal of Applied Management and Entrepreneurship, 12(1), pp. 3-23.

Cassivi, L. (2006). Collaboration planning in a supply chain Supply Chain Management: An International Journal, 11(3), pp. 249-258.

Christopher, M. (2004). Logistics and Supply Chain Management, $3^{\text {rd }}$ Ed., Financial Times/Prentice Hall, New York.

Corsten, D. and Kumar, N. (2003). Profits in the pie of the beholder Harvard Business Review, 81(May), pp. 22-23.

Corsten, D. and Felde J. (2005) Exploring the performance effects of key-supplier collaboration: An empirical investigation into Swiss buyer-supplier relationships, International Journal of Physical Distribution $\mathcal{E}$ Logistics Management, 35 (6), pp. $445-461$.

Coyle, J., Novack, R., Gibson, B. and Langley, C. (2008). Supply Chain Management: A Logistics Perspective, SouthWestern College Publishing, Mason, Ohio.

Crook, T., Giunipero, L., Reus, T., Handfield, R. and Williams, S. (2008). Antecedents and outcomes of supply chain effectiveness: An exploratory investigation Journal of Managerial Issues, 20(2), pp. 161179.

Dai, Z. (2008). Supply chain transformation by ERP for enhancing performance: An empirical investigation Advances in Competitiveness Research, 16(1/2), pp. 8798.

Dess, G. and Robinson, R. (1984). Measuring organizational performance in the absence of objective measures Strategic Management Journal, 5(3), pp. 265273.

Ellram, L. and Hendrick, T. (1995). Partnering characteristics: A dyadic perspective Journal of Business Logistics, 16(1), pp. 41-64.

Feng, C. and Yuan, C. (2006). The impact of information and communication technologies on logistics management International Journal of Management, 23(4), pp. 909-925.

Frohlich, M. and Westbrook, R. (2001). Arcs of integration: An international study of supply chain strategies Journal of Operations Management, 19(2), pp. 185-200.

Forslund H, and Jonsson P. (2009). Obstacles to supply chain integration of the performance management process in buyer-supplier dyads: The buyers' perspective International Journal of Operations $\mathcal{E}$ Production Management, 29(1), pp. 77-95.
GlasBanken (2004). Svensk Glas Återvinning AB, Retrieved January 29th, 2004, from http://www.glasbanken.com/ main.html.

Gooley, T. (1997). The state of third-party logistics in Europe Logistics Management, 36(1), pp. 80A-81A.

Hannon, D. (2001). GM hatches plan to cut 70 days from order cycle time Purchasing, 130(13), pp. 61-62.

Harland, C. (1996). Supply chain management relationships, chains and networks British Journal of Management, 7(S1), pp S63-80.

Harzing, A. (2000). Cross-national industrial mail surveys: Why do response rates differ between countries? Industrial Marketing Management, 29(3), pp. 243-254.

Heide, J. and Stump R. (1995). Performance implications of buyer-supplier relationships in industrial markets: A transaction cost explanation Journal of Business Research, 32(1), pp. 57-66.

Johnson, T. and Owens, L. (2003). Survey response rate reporting in the professional literature American Association for Public Opinion Research, Retrieved October $12^{\text {th }}$ 2007, from www.srl.uic.edu/publist/ Conference/rr_reporting.pdf.

Kaplan, R. and Norton, D. (1996). Linking the balanced scorecard to strategy California Management Review, 39(1), pp. 53-79.

Kaplowitz, M., Hadlock, T. and Levine, R. (2004). A comparison of web and mail survey response rates Public Opinion Quarterly, 68(1), pp. 94-101.

Kaufmann, L and Carter, C. (2002). International supply management systems - the impact of price vs. nonprice driven motives in the United States and Germany Journal of Supply Chain Management, 38(3), pp. 4-17.

Kaufmann, L and Carter, C. (2006). International supply relationships and non-financial performance-A comparison of U.S. and German practices Journal of Operations Management, 24(5), pp. 653-675.

Kauremaa, J. (2006). VMI-tutkimus 2006 Loppuraportti Publications of the Helsinki University of Technology, Retrieved March 14 $4^{\text {th }} 2008$, from http:// www.tuta.hut.fi/logistics/elocore/V MI/ VMI_loppuraportti.pdf.

Krause, D., Ellram, L. (1997). Success factors in supplier development International Journal of Physical Distribution, 27(1), pp. 39-52.

Koh, S., Demirbag M., Bayraktar, E., Tatoglu, E. and Zaim S. (2007). The impact of supply chain management practices on performance of SMEs Industrial Management E Data Systems , 107(1), pp. 103 - 124.

Koh, C.E. Nam, K., Prybutok V., and Lee S. (2007) A value chain perspective of internet practices, e-readiness and organizational performance: A comparison of US and South Korean firms Industrial Management $\mathcal{E}$ Data Systems; 107 (4), pp. 519-536. 
Langley, C., Allen G. and Dale, T. (2004). Third-party logistics study - Results and findings of the 2004 ninth annual study [Retrieved December $3^{\text {rd }}$ 2007] from http:/ /www.de.capgemini.com/m/de/tl/ThirdParty_Logistics_2004.pdf.

Li, S., Ragu-Nathan, B., Ragu-Nathan, T., Rao, S. (2005). Development and validation of a measurement for studying supply chain management practices Journal of Operations Management, 23(6), pp. 618-641.

Li, S., Ragu-Nathan, B., Ragu-Nathan, T., Rao, S. (2006). The impact of supply chain management practices on competitive advantage and organizational performance Omega, 34(2), pp. 107-124.

Lieb, R., Millen, R. and Van Wassenhove, L. (1993). Third party logistics services: A comparison of experienced American and European manufacturers International Journal of Physical Distribution and Logistics Management, 23(6), pp. pp. 35-44.

Locke, R., and Romis, M. (2007). Improving work conditions in a global supply chain Sloan Management Review, 48(2), p. 54.

Matthews, C. (2006). Linking the supply chain to TQM Quality Progress, 39(11), pp. 29-35.

Meindl, P. and Chopra, S. (2006). Supply Chain Management, 3rd Ed., Prentice Hall, Upper Saddle River, New Jersey.

Monczka, R., Trent R. and Handfield, R. (1998). Purchasing and Supply Chain Management, South-Western College Publishing, Cincinnati, Ohio.

Metsä, M. (2000). Eettiset kuluttajat haastavat yritykset toimimaan - USA johtaa Eurooppaa brandayksessa Economic Trends, 2000(1), pp. 38-41.

Nokia (2008) “ Eettiset Vaatimukset, [Retrieved January 30th 2009] from http://www.nokia.fi/nokia/yritysvastuu/ toimitusketju/toimittajavaatimukset/eettisetvaatimukset.

Ogden, S, and McCorriston, E. (2007). How do supplier relationships contribute to success in conference and events management? International Journal of Contemporary Hospitality Management, 19(4), pp. 319327.

Pearcy, D., Giunipero, L. and Wilson, A. (2007). A model of relational governance in reverse auctions Journal of Supply Chain Management, 43(1), pp. 4 -15.

Petison, P. and Johri, L. (2008). Dynamics of the manufacturer-supplier relationships in emerging markets: A case of Thailand Asia Pacific Journal of Marketing and Logistics, 20(1), pp. 76-96.

Power, D. (2008). Capability and practice in procurement collaboration: A vendor's perspective of benefits Operations and Supply Chain Management, 1(2), pp. 72-84.
Saccomano, A. (1998). Keeping SCOR Traffic World, 255(13), pp. 27-28.

Sax, L., Gilmartin S..and Bryant, A. (2003). Assessing response rates and nonresponse bias in web and paper surveys Research in Higher Education, 44(4), pp. 409-432.

Schoenherr, T. and Mabert, V. (2007), The effect of buyerimposed bidding requirements and bundle structure on purchase performance Journal of Supply Chain Management, 43(1), pp. 27-39.

Sengupta, K., Heiser, D. and Cook, L. (2006). Manufacturing and service supply chain performance: A comparative analysis Journal of Supply Chain Management, 42(4), pp. 4-15.

Shin, H., Collier, D. and Wilson, D. (2000). Supply management orientation and supplier/buyer performance Journal of Operations Management, 18(3), pp. 317-333.

Simchi-Levi, D., Kaminsky, P. and Simchi-Levi, E. (2007). Designing and managing the supply chain, $3^{\text {rd }} \mathrm{Ed}$. , McGraw-Hill/Irwin, New York.

Singh, N., Lai, K. and Cheng, T. (2007). Intra-organisational perspectives on IT-enabled supply chains Communications of the ACM, 50(1), p. 59.

Stuart, I. and McCutcheon, M. (2000). The manager's guide to supply chain management Business Horizons, 30(2), pp. 35-44.

van der Vaart, T., van Donk, D.P. (2008). A critical review of survey-based research in supply chain integration International Journal of Production Economics, 111(1), pp. 42-55.

Vázquez, R., Iglesias, V. and Rodríguez-del-Bosque, I. (2007). The efficacy of alternative mechanisms in safeguarding specific investments from opportunism The Journal of Business $\mathcal{E}$ Industrial Marketing, 22(7), pp. 498-507.

Venkatraman, N. and Vasudevan Ramanujam (1986). Measurement of business performance in the absence of objective measures Strategic Management Review, 11(4), pp. 801-814.

Walter, A., Ritter, T. (2003). The influence of adaptations, trust, and commitment on value-creating functions of customer relationships Journal of Business, 18(4/5), pp. 353-365.

Wisner, J., Tan, K. and K. Leong (2008). Principles of Supply Chain Management, $2^{\text {nd }}$ Ed., South-Western Cengage Learning, Mason, Ohio. 
Dr. Karen Spens is Professor of Supply Chain Management and Corporate Geography at Hanken School of Economics in Helsinki, Finland. She earned her Ph.D. from Hanken in 2001, and has since published articles in logistics journals such as International Journal of Physical Distribution and Logistics Management and the International Journal of Logistics Management as well as other international journals. She has also edited several special issues for different journals and is currently the regional editor for IJPDLM. Her research interests include humanitarian logistics, health care related research and methodological issues in logistics and supply chain management.

Dr. Joel Wisner is Professor of Supply Chain Management at the University Nevada, Las Vegas. He earned his Ph.D. in Supply Chain Management from Arizona State University in 1991. He is currently keeping busy writing supply chain management textbooks. His research interests are in quality assessment and improvement strategies along the supply chain. His articles have appeared in numerous journals including Journal of Business Logistics, Journal of Operations Management, Journal of Supply Chain Management, Journal of Transportation, Production and Operations Management Journal, and Quality Management Journal. More information about Dr. Wisner can be found at his website: www.scsv.nevada.edu/ wisnerj 